\title{
Application of a "Sealed Can Technique" and CR-39 detectors for measuring radon emanation from undamaged granitic ornamental building materials
}

\author{
A.O. Ferreira, B.R.S. Pecequilo and R.R. Aquino \\ Environmental Radiometric Division, Instituto de Pesquisas Energéticas e Nucleares, \\ Av. Prof. Lineu Prestes, 2242, Cidade Universitária, 05508-000 São Paulo, SP, Brazil
}

\begin{abstract}
Radon $\left({ }^{222} \mathrm{Rn}\right)$ is the most important cause of exposure to mankind due to natural radioactivity. Radon exhalation depends not only on the ${ }^{226} \mathrm{Ra}$ concentration in the material, but also on other factors such as mineralogy of the region, size and density of grains and porosity of the material. As building materials are one of the major sources of environmental radon, the radiological implications of the use of materials with great content of uranium must be always assessed. In this work, radon exhalation from several undamaged granitic building materials used as ornamental rocks or coating tiles is determined using the "sealed-can technique" and CR-39 solid state nuclear track detectors (SSNTD). Preliminary results for radon concentrations showed values of the same order that literature values, in a range from $99 \mathrm{~Bq} \cdot \mathrm{m}^{-3}$ to $1100 \mathrm{~Bq} \mathrm{~m}^{-3}$. Further, the methodology will be validated with standard sources of ${ }^{222} \mathrm{Rn}$.
\end{abstract}

\section{INTRODUCTION}

\subsection{The Radon}

The exposure due to inhalation of radon is the most significant factor of human irradiation by natural sources [1]. The three natural isotopes of radon, ${ }^{222} \mathrm{Rn},{ }^{219} \mathrm{Rn}$ and ${ }^{220} \mathrm{Rn}$, each one from the radioactive natural series, respectively of ${ }^{238} \mathrm{U},{ }^{235} \mathrm{U}$ and ${ }^{232} \mathrm{Th}$, [2], are all radioactive and alpha emitters.

Considering the short half-life of ${ }^{220} \mathrm{Rn}$ and ${ }^{219} \mathrm{Rn}$ and that ${ }^{235} \mathrm{U}$ represent only $0,71 \%$ of natural uranium [1], the greatest radiological concern focuses on the determination of the isotope of ${ }^{222} \mathrm{Rn}$. The radon (radon, for simplicity, hereafter, means the isotope of ${ }^{222} \mathrm{Rn}$ ) is a noble gas following the ${ }^{226} \mathrm{Ra}$ decay in the ${ }^{238} \mathrm{U}$ series. As a noble gas, radon does not interact with other elements and can easily emanate from the soil or rocks and concentrate indoors [3]. As uranium and radium are present in almost everything, like soil, rocks, water, building materials, etc., radon often is present in the surrounding air. However, the concentration levels are mainly determined by the following factors: floor covering (eg. pavement, buildings and vegetation), altitude, soil porosity and grain size, temperature, air pressure, moisture content of the soil, weather and seasons.

\subsection{Radon Measurements}

Radon and its progeny can be detected by active and/or passive detection techniques [4]. In the present work, the radon and its daughters were detected by the passive technique of Solid State Nuclear Tracks Detectors (SSNTD) [4]. The operation of SSNTD detectors is based on the fact that heavy charged particles interact with the detector, leaving a latent track of the order of 50 to $100 \AA$, which, after specific chemical etching, can be visualized under an optical microscope [5].

To measure only radon, a diffusion chamber must be used, allowing solely the passage of radon, so the detector will register only the alpha emissions generated inside the diffusion chamber [4]. The radionuclides concentrations activities will be determinate using a calibration factor, relating the track densities with activities. 
(a)

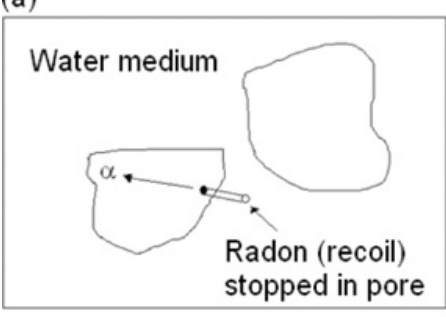

(b)

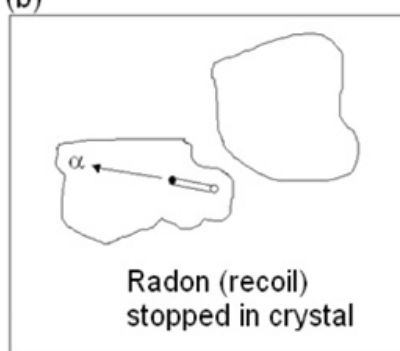

(c)

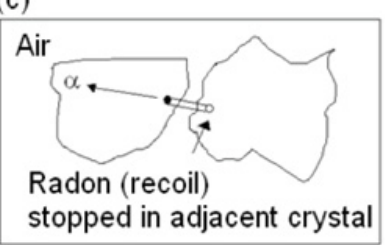

Figure 1. Some processes of radon release.

\subsection{Radon Exhalation}

Exhalation is the number of radon atoms released from the surface of a specific material by emanation and diffusion.

Radon atoms are generated by alpha decay of ${ }^{226} \mathrm{Ra}$ with an initial energy of $86.0 \mathrm{keV}$ and range in solid materials in the orders of tens of $\mathrm{nm}$. Depending on the original site of the atom of ${ }^{226} \mathrm{Ra}$ in the structure and direction of recoil (Fig. 1), radon atoms can escape into the pores (micropores, cracks) (Fig. 1a), or be keeped in mineral grains (Fig. 1b and Fig. 1c) [6]. For samples consisting of small grains, the pore spaces may not be enough to stop the recoil atom, consequently, some of the radon atoms can be implanted in neighborhood mineral grains, so, when released later, they are termed indirect recoil atoms [7]. When the pores are filled with water, the recoil atom is stopped and is free to diffusion; usually the moisture in the pores increases the emanation coefficient in relation to the pores filled with air. However, the atoms will diffuse more into the material if the pores are filled with air than the water [8]. This way, the exhalation of radon is quite complex and depends on many factors such as, for example, concentration and distribution of ${ }^{226} \mathrm{Ra}$ [8], grain size [7], moisture content [9] and mineralogical composition [6] of the material.

Usually, the indoors internal exposure index for radon is assessed through the activity concentration of ${ }^{226} \mathrm{Ra}$. However, depending on the building material composition, it is possible that the real radon concentration in the air would be higher or lower when comparing with the ${ }^{226} \mathrm{Ra}$ content, so, it is of great importance the knowledge of radon exhalation.

\section{MATERIAL AND METHOD}

Six undamaged granite samples (Tab. 1) in the commercial form of $10 \times 10 \times 2 \mathrm{~cm}$, were collected and directly exposed during three months in a sealed cylinder with CR-39 SSNTD.

\subsection{Sealed Can Technique}

The determination of radon and its progeny was performed by passive detection technique with solid state nuclear track detection (SSNTD), using the "sealed can technique", [10-12]. Each sample was 
Table 1. Granite undamaged samples assessed in this work.

\begin{tabular}{ccc}
\hline ID & Type & Trade name \\
\hline GVI & Granite & Vermelho Itaipu \\
GIM & Granite & Imperador \\
GVV & Granite & Verde Vulcano \\
GSFG & Granite & Sea Foam Green \\
GBD & Granite & Bege Dunas \\
GPG & Granite & Paraná Green \\
\hline
\end{tabular}

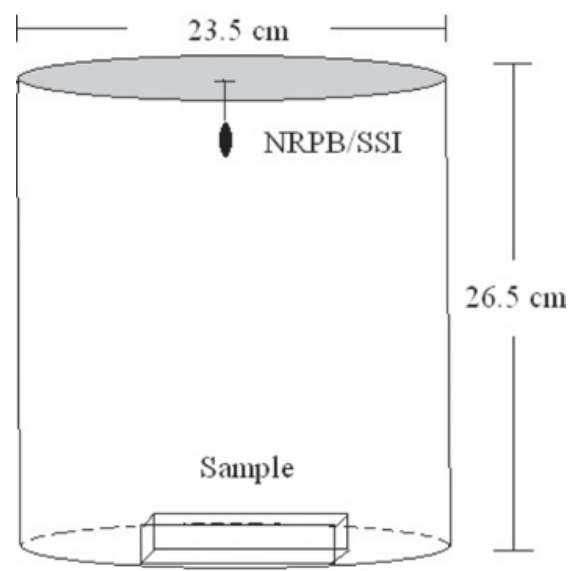

Figure 2. Sealed Can Technique used in the present work.

placed inside a plastic cylindrical container facing a CR-39 track detector into a diffusion chamber model NRPB/SSI [13] (Fig. 2). The container was then sealed for approximately three months.

After exposure, the detectors were etched during 5.5 hours with a $\mathrm{KOH} 30 \%$ solution at $80^{\circ} \mathrm{C}$ [13], and readed under a Zeiss optical microscope [14].

The radon concentration $\mathrm{C}_{\mathrm{Rn}}$ in $\left(\mathrm{Bq} \mathrm{m}^{-3}\right)$ was determined by the following equation:

$$
C_{R n}=\frac{D}{F . t}
$$

Where $\mathrm{D}$ is the tracks density in (tracks. $\mathrm{cm}^{-2}$ ), $\mathrm{t}$ is the exposition time in (hours) and $\mathrm{F}$ is the calibration factor (detector efficiency) of $2.8 \pm 0.2$ tracks. $\left.\mathrm{m}^{3}\right) \cdot\left(\mathrm{cm}^{-2} \cdot \mathrm{Bq}^{-1} \cdot \mathrm{h}^{-1}\right)$ [13].

The surface exhalation rate of radon $\mathrm{E}_{x}^{\text {in }}, \mathrm{Bq} \cdot \mathrm{m}^{-2} \cdot \mathrm{h}^{-1}$, was calculated as follows:

$$
E_{X}=\frac{C V \lambda}{A\left[T+\frac{1}{\lambda}\left\{e^{-\lambda T}-1\right\}\right]}
$$

Where $\mathrm{C}$ is the integrated radon exposition measured by the CR-39 SSNTD (Bq.m $\left.{ }^{-3} \cdot \mathrm{h}\right), \mathrm{V}$ is the effective volume of the container, $\lambda$ is the decay constant of radon $\left(\mathrm{h}^{-1}\right), \mathrm{T}$ is the exposition time $(\mathrm{h})$, and $\mathrm{A}$ is the area covered by the container $\left(\mathrm{m}^{2}\right)[12]$.

\section{RESULTS}

The radon activity concentration, the surface exhalation rate and the mass exhalation rate were calculated by the equations 1, 3 and 4 respectively and the results are show in the following figures.

The results of Fig. 3 show that the concentration of radon in all measured samples varies from $99 \mathrm{~Bq} \cdot \mathrm{m}^{-3}$ to $1100 \mathrm{~Bq} \cdot \mathrm{m}^{-3}$, in good agreement with the values for similar rocks found by Moura [15], 


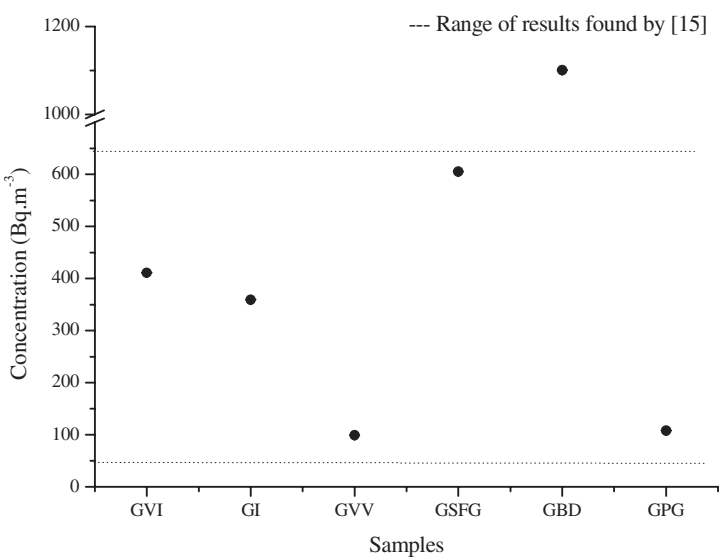

Figure 3. Radon activity concentration (Bq. $\mathrm{m}^{-3}$ ).

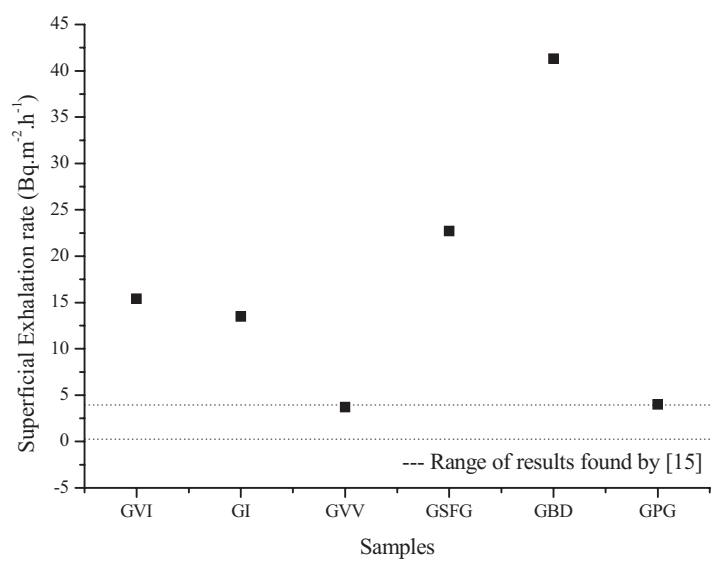

Figure 4. Superficial Exhalation rate $\left(\mathrm{Bq} \cdot \mathrm{m}^{-2} \cdot \mathrm{h}^{-1}\right)$.

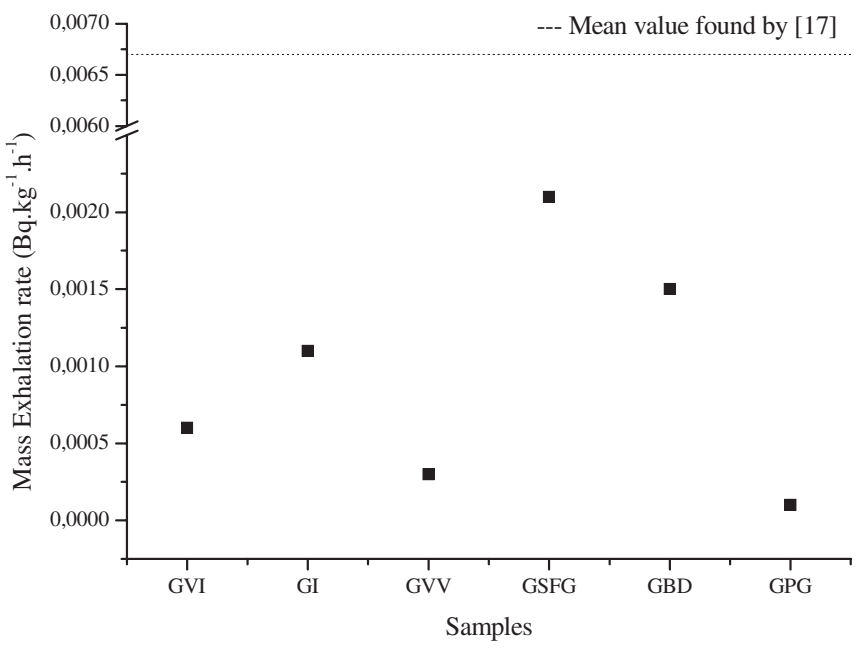

Figure 5. Mass exhalation rate $\left(\mathrm{Bq} \cdot \mathrm{kg}^{-1} \cdot \mathrm{h}^{-1}\right)$. 
ranging from $26 \mathrm{~Bq} \cdot \mathrm{m}^{-3}$ to $643 \mathrm{~Bq} \cdot \mathrm{m}^{-3}$ (dashed lines in Fig. 3). The surface exhalation rate (Fig. 4) varies from $3.7 \mathrm{~Bq} \cdot \mathrm{m}^{-2} \cdot \mathrm{h}^{-1}$ to $41.3 \mathrm{~Bq} \cdot \mathrm{m}^{-3}$. Similar values for the superficial exhalation rate were reported by Moura [15], ranging from 0.24 Bq. $\mathrm{m}^{-2} \cdot \mathrm{h}^{-1}$ to $3.93 \mathrm{~Bq} \cdot \mathrm{m}^{-2} \cdot \mathrm{h}^{-1}$ (dashed lines in Fig. 4). The mass exhalation rate (Fig. 5) varies from $0.1 \mathrm{mBq} \cdot \mathrm{kg}^{-1} \cdot \mathrm{h}^{-1}$ to $2.1 \mathrm{mBq} \cdot \mathrm{kg}^{-1} \cdot \mathrm{h}^{-1}$. Kobeissi et al [17] found a mean value of $6.7 \mathrm{mBq} \cdot \mathrm{kg}^{-1} \cdot \mathrm{h}^{-1}$ for mass exhalation rate for sands (dashed line in Fig. 5), a higher value than the results found in the present work. However, considering that radon exalation is easier in sands that in granites, the granite results are to be lower.

\section{CONCLUSIONS}

The results for the radon concentration are in good agreement with literature for similar rocks. The measured surface exhalation rate was higher than the mass exhalation rate, allowing to conclude that the sample surface area has a major role in rising the exhalation rate, comparing with the sample mass. However, more measurements are needed in order to obtain suitable relationships between and radon concentrations and surface areas for several materials.

\section{Acknowledgements}

This work was supported by CNEN (Brazilian National Commission of Nuclear Energy).

\section{References}

[1] UNSCEAR - United Scientific Committee on the Effects of Atomic Radiation (UNSCEAR), The 1993 Report to the General Assembly with scientific Annexes. New York: United Nations, (1993).

[2] NCRP-97, National Council on Radiation Protection and Measurements, Measurement of radon and radon daughter in air, NCRP-97, (1998).

[3] EISENBUD, M. Environmental Radioactivity. 2nd ed. Academic Press, Orlando, (1987).

[4] PAULO, S. R., Dosimetria ambiental de Rn-222 e filhos: Medida da eficiência absoluta do CR-39 Levando-se em conta os efeitos do Plate-out e fatores ambientais, (1991), Tese de Doutorado, UNICAMP, IFGW, Campinas.

[5] FLEISCHER, R.L., PRICE, P.B., WALKER, R.M. Nuclear Tracks in Solids: Principles and Applications. Univ. of California Press, Berkeley, (1975).

[6] SAKODA, A., HANAMOTO, K., ISHIMORI, Y., KATAOKA, T., KAWABE, A.,YAMAOKA, K. First model of the effect of grain size on radon emanation. Applied Radiation and Isotopes., v. 68 (2009) p. 1169-1172.

[7] SEMKKOW, T. M. Recoil-emanation theory applied to radon release from mineral grains. Geochimica et Cosmochimica Acta., vol 54, (1978) p. 425-440.

[8] MORAWSKA, L AND PHILLIPS. Dependence of the radon emanation coefficient on radium distribution and internal struture of the material. Geochimica et Cosmochimica Acta., vol 57, (1993) p. 1783-1797.

[9] FLEISCHER, R. Moisture and 222Rn Emanation. Health Physics., vol 52, (1986), n6, p. 797-799.

[10] KHAN, A. J., RAJENDRA PRASAD, TYAGI, R. K. Measurement of radon exhalation rate from some building materials. Nucl. Tracks Radiat. Meas., Vol. 20, (1992), No. 4, pp. 609-610.

[11] FAHEEM, M., MATIULLAH. Radon exhalation and its dependence on moisture content from samples of soil and building materials. Radiation Measurement., Short communication, (2008).

[12] MAHUR, A.K., KUMAR, R., SONKAWADE, R.G., SENGUPTA, D., PRASAD, R. Measurement of natural radioactivity and radon exhalation rate from rock samples of Jaduguda uranium mines and its radiological implications. Nuclear Instruments and Methods in Physics Research B., v. 266, (2008), p. 1591-1597. 
[13] ORLANDO, C. ORLANDO, PATRIZII, P.L, TOMMASINO, L. TONNARINI, L., TREVISI, R. AND VIOLA, P. A passive radon dosimeter suitable for workplaces. Radiat. Prot. Dosim., v. 102 (2002), p. 163-168.

[14] ZEISS, C., KS 100 Imaging System Release 3.0, (1997).

[15] MOURA, C. L., Radioatividade natural e emanação de Rn-222 em rochas ornamentais provenientes de diferentes series magmáticas, (2005), Tese de Doutorado, UNESP Rio Claro, Pós-Graduação em Geologia Regional, Rio Claro.

[16] GUPTA, M., MAHUR, A.K., SONKAWADE, R.G., VERMA, K. D., PRASAD, R. Measurement of radon activity, exhalation rate and radiation doses in fly ash samples fron NTPC Dadri, India. Indian Journal of Pure \& Applied Physics, Vol. 48, (2010), pp 520-523.

[17] KOBEISSI, M. A., EL SALMAD, O., ZAHRAMAN, K., MILKY, S., BAHSON, F., ABUMURAD, K. M. Natural radioactivity measurements in building material in Southern Lebanon. Journal of Environmental Radioactivity, Vol. 99, (2008), pp 1279-1288. 